\title{
PERSOALAN KEAGAMAAN PEREMPUAN PADA NOVEL CINTA DALAM 99 NAMA-MU KARYA ASMA NADIA
}

\author{
Kristiana Surya Lestari, \\ (Pendidikan Bahasa Indonesia, Fakultas Keguruan dan Ilmu Pendidikan, \\ Universitas PGRI Adi Buana Surabaya) \\ klaprillia@gmail.com \\ Shoim Anwar \\ (Pendidikan Bahasa Indonesia, Fakultas Keguruan dan Ilmu Pendidikan, \\ Universitas PGRI Adi Buana Surabaya) \\ shoimanwar@unipasby.ac.id
}

\begin{abstract}
Cinta dalam 99 Nama-Mu are interesting because they tell a girl who wants to be close to God, the character played by the main character and religious issues that occur in the main female characters. This study aims to describe more deeply the female character and religious issues that occur in the novel Cinta dalam 99 Nama-Mu by Asma Nadia, the first print of April 2018. The theory used is the theory of feminism. The main objectives to be achieved in this study, describe the character of the main character and women's religious issues in the novel Cinta dalam 99 Nama-Mu. The method used in the study is descriptive qualitative, because this research is done by reading and taking notes. The data contained in the study are written data about the elements of the story that relate to the characters and religious issues of women in the Cinta dalam 99 Nama-Mu by Asma Nadia. Data analysis used qualitative descriptive analysis, which is used to analyze the elements that build literary works from within, and look for relationships and linkages with these elements.
\end{abstract}

Keywords: Novels, character figures, religious issues.

\section{PENDAHULUAN}

Karya sastra lahir di tengahtengah masyarakat sebagai hasil imajinasi seorang pengarang terhadap gejala-gejala sosial di lingkungan sekitarnya. Karya sastra diciptakan pengarangnya untuk menyampaikan sesuatu kepada penikmat karyanya. Sesuatu yang ingin disampaikan pengarang adalah perasaan yang dirasakan saat bersentuhan dengan kehidupan sekitarnya. Sastra merupakan salah satu objek kajian yang selalu menarik para peneliti karena karya sastra mengisyaratkan gambaran hidup dan kehidupan manusia yang luas dan kompleks (Emzier dan Rohman, 2015:254).
Karya sastra juga merupakan dunia imajinasi yang diciptakan oleh pengarang. Imajinasi yang diciptakan berasal dari diri sendiri dan lingkungan sekitar pengarang. Imajinasi yang diciptakan dari diri sendiri berhubungan dengan kondisi psikologis yang dialami oleh pengarang. Hal tersebut sangat berpengaruh bagi cerita yang akan dituliskan.

Pengaruh terbesar dari kondisi psikis pengarang yaitu pada tokoh cerita. Kebanyakan orang beranggapan bahwa tokoh utama merupakan tokoh yang sama dengan pengarangnya, apalagi jika tokoh tersebut memiliki jenis kelamin yang 
sama. Imajinasi yang diciptakan dari lingkungan sekitar pengarang dapat diartikan bahwa kondisi lingkungan, peristiwa, dan tempat mampu memberi hasrat bagi seorang penulis untuk mengabadikannya ke dalam sebuah tulisan yaitu karya sastra.

Salah satu bentuk karya sastra yang membicarakan manusia dengan segala perilaku dan kepribadiannya dalam kehidupan adalah novel. Membaca karya fiksi berupa novel berarti kita menikmati cerita, menghibur diri untuk memperoleh kepuasaan batin, memberikan kesadaran mengenai gambaran kehidupan dan belajar untuk menghadapi masalah yang mungkin akan kita mengenai gambaran kehidupan dan belajar untuk menghadapi masalah yang mungkin akan kita alami. Sebagai karya, novel merupakan hasil ungkapan, ide-ide, gagasan dan pengalaman pengarang terhadap lingkungan dan kehidupan. Sebagai karya imajiner, novel menawarkan berbagai persoalan tersebut dengan penuh kesungguhan dan kemudian diungkapkan kembali melalui sarana sastra dengan pandangannya. Karya sastra yang ditulis oleh penulis pada dasarnya menampilkan kejadian atau peristiwa. Kejadian atau peristiwa yang terdapat dalam karya sastra dihidupkan oleh tokoh-tokoh yang memegang peran penting dalam cerita.

Melalui tokoh inilah seorang pengarang menciptakan peristiwaperistiwa yang melukiskan kehidupan manusia yang berbeda karena setiap manusia memiliki karakter yang berbeda dengan manusia lainnya. Perbedaan itulah yang menyebabkan adanya kejadian atau peristiwa yang terjadi dalam karya sastra. Kejadian atau peristiwa tersebut berhubungan dengan persoalan, baik persoalan dengan orang lain, persoalan dengan lingkungan, persoalan dengan diri sendiri, maupun persoalan dengan Tuhan.

Objek penelitian ini adalah novel tentang Cinta dalam 99 Nama-Mu Karya Asma nadia. Novel ini menceritakan tentang seorang perempuan bernama Arum. Arum memiliki persoalan atau persoalan dengan keagamaan Arum juga memiliki penyakit mematikan kanker yang sudah menjalar ke seluruh tubuhnya, Arum juga memiliki persoalan dengan seorang remaja bernama Alif yang sangat suka bergonta ganti pasangan, dan suka menganggap remeh perempuan. Didalam novel ini juga mengandung sisi feminisme dalam perempuan, novel ini juga spiritual yang kuat yaitu tentang agama Islam.

Novel tentang Cinta dalam 99 Nama-Mu memiliki cerita tentang persoalan keagamaan perempuan, dimana sang perempuan sangat ingin dekat kepada Tuhan. Persoalan keagamaan perempuan yang inginkan untuk bisa lebih dekat kepada-Nya, membuat novel ini menggunakan analisis feminisme dimana dalam novel ini juga menceritakan penindasan terhadap perempuan atau meremehkan keberadaan perempuan yang dianggap lemah oleh laki-laki. Dalam novel ini juga menceritakan kisah percintaan Arum dan Alif yang dimana Arum pernah ditindas oleh Alif karena meremehkan perempuan, begitu pula dengan Alif yang mengalami hal yang serupa mengalami persoalan tentang keagamaan dan membutuhkan mendekatkan diri kepada Tuhan.

Dari paparan di atas, penelitian ini ingin menjawab permasalah, bagaiaman karakter tokoh utama perempuan dan bentuk persoalan 
keagamaan perempuan dalam novel "Cinta dalam 99 Nama-Mu" Karya Asma Nadia. Hasil dari penelitian ini diharapkan dapat bermanfaat dalam memberikan perkembangan ilmu sastra dan menjadi sarana pembelajaran dan pengetahuan selanjutnya.

Dalam artikel ini, teori feminisme dan keagamaan sebagai dasar kajian karena kedua konsep tersebut sesuai dengan gambaran Cinta dalam 99 Nama-Mu karya Asma Nadia.

Feminisme adalah Sebuah kesadaran tentang adanya ketidakadilan yang sistematis bagi prempuan di seluruh dunia (Emzier dan Rohman, 2015). Teori ini bertujuan memahami dan menjelaskan hakikat ketimpangan gender dengan menyaksikan peran sosial perempuan dan pengalaman hidupnya (Astuti, 2011:8). Bentuk awal feminisme telah mengalami kritikan, karena hanya mempertimbangkan kaum putih, kelas menengah, dan yang terdidik. Lalu hal ini menimbulkan bentuk feminisme yang multi kulturalis. Teori feminis juga telah merambah ke berbagai bidang studi, seperti sosiologi, ekonomi, antropologi, psikologi, sastra, hukum, dan sebagainya. Teori-teori feminis berfokus pada ketimpangan gender, relasi kuasa, dan seksualitas.

Kata feminist dalam berbagai kamus sering diartikan sebagai kata benda (noun) atau kata sifat (adjective) yang diakitkan dengan kata feminism. Dalam Merriam Webster's Dictionary and Thesaurus, feminist merupakan kata sifat (adjective) dari feminism yang berarti; (a) teori tentang kesetaraan politik, ekonomi dan sosial berdasarkan jenis kelamin, (b) aktivitas yang diorganisasi atas nama hak-hak dan kepentingan perempuan.
Kata feminist sebagai kata benda (noun) berarti pula supporter atau pendukung feminism, atau kata sifat (adjective) yang berarti berhubungan dengan atau mendukung persamaan hak bagi perempuan. Sedangkan dalam Oxford English Dictionary (OED) feminism berarti advokasi hak-hak perempuan atas dasar kesetaraan jenis kelamin. Dalam Kamus Besar Bahasa Indonesia, hanya ditemukan istilah feminism yang berarti gerakan perempuan yang menuntut persamaan hak sepenuhnya antara kamu perempuan dan laki-laki. Feminisme dalam pandangan para ahli dan aktivis feminis memiliki beragam makna. Linda Gordon mengartikan feminism sebagai "an analysis of women's subordination for the purpose of figuring out how to change it" (suatu analisis terhadap subordinasi perempuan untuk tujuan mencari tahu bagaimana mengubahnya). Bagi Gordon, feminism juga berarti "sharing in an impulse to increase the power and autonomy of women in their families, communities, and/or society" (sharing dalam suatu dorong hati untuk meningkatkan kuasa dan otonomi perempuan dalam keluarga, komunitas dan/atau masyarakat mereka).

Dari uraian di atas, dapat disimpulkan bawa feminisme adalah sebuah kesadaran tentang adanya ketidakadilan yang sistematis bagi perempuan di seluruh dunia.

\section{METODE PENELITIAN}

Metode yang digunakan dalam penelitian ini adalah metode deskriptif kualitatif. Peryataan ini sejalan dengan pendapat Nazir (2011:54) manusia, suatu objek, suatu set kondisi, suatu sistem pemikiran, ataupun suatu kelas peristiwa pada 
masa sekarang." Menjelaskan cara kerja peneliti "kerja peneliti, bukan saja memberikan gambaran terhadap fenomena-fenomena, tetapi juga menerangkan hubungan, menguji hipotesis-hipotesis, membuat prediksi serta mendapat makna dan implikasi dari suatu masalah yang lain dipecahkan. Metode yang digunakan penulis dalam analisis ini adalah metode deskriptif kualitatif.

\section{HASIL DAN PEMBAHASAN}

Persoalan Keagamaan Perempuan Pada Novel "Cinta dalam 99 NamaMu"

Persoalan

Keagamaan

Perempuan Pada Novel "Cinta dalam 99 Nama-Mu" karya Asma Nadia dapat dilihat dari segi masalah, di antaranya : 1) karakter tokoh utama perempuan pada novel cinta dalam 99 nama-Mu, dan 2) bentuk persoalan keagamaan perempuan pada novel cinta dalam 99 nama-Mu.

\section{1) Karakter Tokoh Utama Perempuan pada Novel Cinta dalam 99 Nama-Mu}

Robert (dalam Patty, 1982:86) memberi batasan bahwa karakter adalah totalitas keadaan dan cara redaksi jiwa terhadap perangsangannya. (Nursisto, 2000:105) mengatakan bahwa karakter atau perwatakan adalah sikap batin manusia yang mempengaruhi segenap pikiran dan perbuatannya. Watak dipengaruhi lingkungan, kebiasaan, dan pendidikan. Robert (dalam Patty, 1982:86) memberi batasan bahwa karakter adalah totalitas keadaan dan cara redaksi jiwa terhadap perangsangannya. (Nursisto, 2000:105) mengatakan bahwa karakter atau perwatakan adalah sikap batin manusia yang mempengaruhi segenap pikiran dan perbuatannya. Watak dipengaruhi lingkungan, kebiasaan, dan pendidikan.

Karakter tokoh merupakan salah satu unsur intrinsik karya sastra di samping tema, sudut pandang, amanat alur dan latar/setting. Penokohan ialah cara pengarang menggambarkan karakter tokoh-tokoh dalam cerita. Sementara tokoh ialah orang/pelaku yang berperan dalam cerita.

"Doa adalah jalan yang bisa kita tempuh agar tetap bisa bersilahturahim dengan orangorang yang tak lagi bisa kita sapa," kata Pak dahlan tetap memegang buku, menutup perbincangan malam. (Nadia, 2018:102)

Kutipan diatas menunjukkan salah satu karakter sedih yang dialami oleh karakter tokoh utama perempuan dalam cerita novel tersebut membuat tokoh utama ini harus berjuang untuk tidak tampak sedih.

Menurut Nurgiantoro (2009:176188), selain terdapat tokoh utama, tokoh tambahan, tokoh protaganis, dan tokoh antagonis, terdapat juga sejumlah ragam pelaku yang lain. Adapun ragam pelaku (tokoh) yang lainnya diuraikan berikut ini.

a) Tokoh sederhana adalah tokoh yang hanya memiliki suatu kualitas pribadi tertentu, suatu sifat-watak yang tertentu saja. Sebagai seorang tokoh manusia, ia tidak diungkap berbagai kemungkinan sisi kehidupannya.

b) Tokoh kompleks adalah tokoh yang kurang akrap dan kurang dikenal sebelumnya. Tingkah lakunya sering tidak terduga dan memberikan efek kejutan pada pembaca.

c) Tokoh dinamis adalah tokoh yang memiliki perubahan dan perkembangan kejiwaan (batin) 
dalam keseluruhan penampilannya.

a) Tokoh statis adalah tokoh cerita yang esensial tidak mengalami perubahan dan perkembangan perwatakan sebagai akibat adanya peristiwa-peristiwa yang terjadi.

2) Bentuk Persoalan Keagamaan Perempuan pada Novel Cinta dalam 99 Nama-Mu

Pengertian Agama dalam kamus besar Bahasa Indonesia, kata 'agama' berarti suatu sistem, prinsip kepercayaan terhadap Tuhan (Dewa dsb) dengan ajaran kebaktian dan kewajiban-kewajiban yang bertalian dengan kepercayaan itu. Kata 'agama' dapat juga didefinisikan sebagai perangkat nilai-nilai atau normanorma ajaran moral spiritual kerohanian yang mendasari dan membimbing hidup dan kehidupan manusia, baik sebagai individu maupun sebagai warga masyarakat. Permasalahan agama sendiri suatu pertikaian antar agama baik antar sesama agama itu sendiri, maupun antar agama satu dengan agama lainnya. Seperti yang ada dalam pembahasan yang mengenai tentang persoalan keagamaan a) Kurang dekatnya dengan Allah, dan yang ke b) Jarang beribadah.

\section{a. Kurang Dekat Dengan Allah}

Penyebab utama kurang dekatnya dengan Allah karena adanya kurang perhatian dari orang tua yang mengajarkan bagaimana untuk dekat kepada Allah melalui shalat atau membaca buku-buku tentang $\mathrm{Al}$ quran dan sebagainya. Karena bila dekat dengan Allah itu membuat hati nyaman dan tentram, saat meminta bantuan atau berdoa kepada Allah yang maha kuasa. Cliffort eertz mengistilahkan agama sebagai 1) Sebuah sistem symbol-simbol yang berlaku untuk, 2) Menetapkan suasana hati dan motivasi-motivasi yang kuat, yang meresapi dan yang tahan lama dalam diri manusia, 3) Merumuskan konsep-konsep mengenai suatu tatanan umu eksistensi dan 4) Membungkus konsep-konsep ini dengan semacam pancaran faktualitas, sehingga, 5) suasana hati dan motivasi-motivasi itu tampak realistis.

Jejak kuasa-Nya, kemahabesaranNya, akankah ditemukannya di tempat seperti ini? (Nadia, 2018:72)

Semua yang dikatakan orang tua itu berujung pada satu kesadaran bahwa Allah Swt, tak pernah sedikit pun meninggalkan hambaNya yang mau memilih jalan lurus. (Nadia, 2018:151)

Kutipan diatas menggambarkan bahwa tokoh utama kurang dekat dengan Allah, karena jarangnya beribadah dan memuliakan nama Allah. Namun pada usianya yang menginjak 23 tahun dia mulai berubah untuk mau mendekatkan diri kepada Allah dan memohon kepada Allah.

Allah memiliki kuasa yang tak terhingga, kemahabesaranNya tidak tertandingi oleh apapun. Bahkan kita tidak tahu apa yang telah Allah siapkan untuk kita di dunia akhirat nantinya. Maka dari itu kita tidak boleh lupa akan kebesaranNya yang sangat luas. Allah tak pernah tidur dan selalu melihat apa yang dilakukan anak-anakNya di dunia ini, bahkan Allah akan menuntun anakNya yang salah jalan untuk kembali pada jalan yang benar.

\section{b. Jarang Beribadah}

Saat kecil mungkin atau seharusnya sudah diajarkan untuk beribadah shalat atau lainnya untuk 
menyembah Allah dan memuliakan nama-Nya. Karena beribadah adalah yang paling utama untuk menunjukkan betapa setianya kita terhadap Allah. Biasanya penyebab kemalasan karena banyak memiliki dosa, tidak pernah diajarkan untuk shalat, sering membicarakan orang atau bergosip.

Selama ini, bisa dibilang sajadah jarang terbentang di rumah mereka.

Peralatan shalat Arum pun, Bik Nah, pembantu mereka yang membelikan. Ia juga yang mengajarkan Arum shalat sejak mendapat haid pertama. (Nadia, 2018:26)

Menyatakan bahwa selama ini jarang sekali atau hampir tidak pernah ada sajadah terbentang untuk shalat. Anak mereka Arum selama ini juga tidak pernah diajarkan apa itu shalat dan yang mengajarkan shalat selama ini pembantu rumah tangga Arum yang mengajarkan bagaimana shalat setelah mendapat haid pertama dan bagaimana membaca ayat-ayat yang ada di al-quran dan menghafal 99 namaMu.

\section{SIMPULAN}

Berdasarkan hasil penelitian dan pembahasan, dapat disimpulkan bahwa karakter utama tokoh perempuan dalam novel Cinta dalam 99 Nama-Mu karya Asma Nadia meliputi : karakter utama tokoh perempuan dan persoalan keagamaan. Karakter tokoh utama perempuan memiliki 4 karakter dalam cerita 1) penyedih, 2) ceria, 3) pemarah, dan 4) penakut. Sedangkan persoalan keagamaan memiliki 2 persoalan 1) kurang dekat dengan Allah dan 2) jarang beribadah.

Mendeskripsikan karakter tokoh utama perempuan dalam novel Cinta dalam 99 Nama-Mu karya Asma Nadia. Mendeskripsikan persoalan kegamaan perempuan dalam novel Cinta dalam 99 Nama-Mu karya Asma Nadia, khususnya mendekatkan diri kepada Tuhan.

Apa yang kita miliki di dunia ini adalah sepenuhnya milik Allah Tuhan kita, apa yang diberikan kepada kita adalah milik Allah sepenuhnya bahkan hidup kita adalah milik Allah. Mati pun milik Allah, karena apa yang menjadi milik kita itu hanya sementara tetapi milik Allah itu sangat abadi seperti kita yang tinggal di dunia ini hanya sementara dan akan kembali padaNya suatu saat nanti.

\section{DAFTAR PUSTAKA}

Astuti, Tri Marhaeni P. 2011. Konstruksi Gender dalam Realitas Sosial. Semarang: Unnes Press.

Cliffort, Geertz. 1992. Kebudayaan dan Agama. Jogyakarta : Kanisius.

Nadia, Asma. 2018. Cinta dalam 99 Nama-Mu. Jakarta: Penerbit Republika.

Nurgyantoro, Burhan. 2009. Teori Pengkajian Fiksi. Yogyakarta: Gadjah Mada University Press.

Rohman, Saifur dan Emzir. 2016. Teori dan Pengajaran Sastra. Jakarta: Rajawali Press. 